\title{
Effect of salt stress on concentration of nitrogen and phosphorus in root and leaf of strawberry plant
}

\author{
Mehmet Ali Demiral*
}

Department of Soil Science and Plant Nutrition, Faculty of Agriculture, University of Adnan Menderes, Aydın, Turkey

\section{Article Info}

Received : 02.03.2017

Accepted : 23.05 .2017

\begin{abstract}
In this study the effect of salt stress on the concentrations of nitrogen (N) and phosphorus (P) in the leaves and the roots of two strawberry (Fragaria vesca L.) cultivars (Camarosa and Sweet Charlie) was investigated on cold stored bare-rooted seedlings grown in buckets filled with coarse sand. The treatments consisting of no- $\mathrm{NaCl}$ control, 1760, 2400, and $3040 \mathrm{mg} \mathrm{L}^{-1}$ of $\mathrm{NaCl}$ in half-strength Hoagland nutrient solution were applied to the plants for six months. During the experiment, leaf and root sampling were performed two times with five months interval. Roots and leaves of the plants were analyzed for $\mathrm{Na}, \mathrm{Cl}, \mathrm{N}$ and $\mathrm{P}$. Analysis of variance (ANOVA) procedures was performed in Three Factors Completely Randomized Design for plant analysis results. Additionally orthogonal comparison was applied to the significant salinity effects. Cultivar and sampling time affected $\mathrm{N}, \mathrm{P}, \mathrm{Na}$ and $\mathrm{Cl}$ concentrations of the roots significantly. Cultivarsampling time and sampling time-salinity interactions were significant for the $\mathrm{N}, \mathrm{P}$ and $\mathrm{Na}$ concentrations of the roots. Salinity solely affected $\mathrm{Cl}$ concentrations of the roots significantly. All the treatments affected the concentrations of $\mathrm{P}, \mathrm{Na}$ and $\mathrm{Cl}$ of the leaves significantly. The $\mathrm{N}$ concentrations of the leaves were affected significantly by only sampling time. Cultivar-salinity and sampling time-salinity interactions were found significant in the leaf $\mathrm{N}$ concentrations of the plants. The results show that the cultivars probably have different strategies in arrangement of $\mathrm{N}$ and $\mathrm{P}$ composition under salinity.
\end{abstract}

Keywords: $\mathrm{NaCl}$ salinity, Fragaria vesca L., Camaraso, Sweet Charlie, mineral nutrients.

\section{Introduction}

The increasing urbanization has expedited the demand of out-of-season strawberry growing all over the world. Aforesaid production has been mainly realized in greenhouse conditions and provided a momentous economic contribution to the growers. However, the pressure on the limited sources of good quality irrigation water has promoted the usage of relatively low quality, mostly saline, irrigation water in the production. Additionally higher yield expectation increased the excessive fertilizer application. These phenomena increased the salinity hazard in the soils of the production areas.

An increase in soil salinity commonly results in a reduction of water intake of plants. Passive nutrient uptake of the plants is related to water intake and any decrease in water availability causes to a reduction in uptake of many plant nutrients. Additionally the imbalance in composition of saline soil solution can also cause to uptake of some ions in excessive amounts such as $\mathrm{Cl}$, Na and $\mathrm{Mg}$. An increase in the concentration of these ions either has a toxic effect directly to the plants or promotes imbalance in plant nutrient metabolism

\footnotetext{
${ }^{*}$ Corresponding author.

Department of Soil Science and Plant Nutrition, Faculty of Agriculture, University of Adnan Menderes, Aydın, Turkey

Tel.: +902567727022

e-ISSN: 2147-4249

E-mail address: mademiral@yahoo.com DOI: 10.18393/ejss.319198
} 
(Ghafoor et al., 2004). According to Orcutt and Nielsen (2000) the most interesting interaction between salinity and macronutrient uptake is that between salinity and $\mathrm{N}$ accumulation. Botella et al. (1997) reported that $\mathrm{NaCl}$ reduced the accumulation of nitrate and ammonium when provided together to the plant. On the other hand limitations of $\mathrm{P}$ can occur in glycophytes like strawberry exposed to high salinity (Gorham, 1992). According to Kalifa et al. (2000) crop tolerance to high $\mathrm{NaCl}$ concentrations is partly related to inorganic $\mathrm{P}$ availability. High $\mathrm{NaCl}$ caused reduced $\mathrm{P}$ uptake in several crop species. Both root uptake and translocation of $\mathrm{P}$ to shoots were depressed. All these processes result in lower crop yields. Strawberry species are very salt sensitive (Larson, 1994) and suffer reductions in growth, quality, and yields (Awang et al., $1993 \mathrm{a}, \mathrm{b}$ ) at soil electrical conductivities (ECe) of above $1 \mathrm{dS} \mathrm{m}^{-1}$ (Carter, 1981). The species however, differ in their salt tolerance (Awang et al., 1993 a,b). The objectives of this research were to evaluate the effect of increasing $\mathrm{NaCl}$-induced salinity on the concentrations of $\mathrm{N}$ and $\mathrm{P}$ in strawberry. In particular how salinity interferes with $\mathrm{N}$ and $\mathrm{P}$ concentrations of root and leaf, and how these changes are related to time.

\section{Material and Methods}

\section{Plant material and salinity treatments}

Two strawberry cultivars, Camarosa and Sweet Charlie were grown in high plastic tunnel at $25 \pm 10{ }^{\circ} \mathrm{C}, 75 \pm$ 25\% Rh and natural photoperiod during Fall 2004 and Spring 2005. Cold stored bare-rooted strawberry seedlings were planted in 5-L buckets filled with coarse sand (0.6-0.8 $\mathrm{mm}$ particle size) on September 30 , 2004. Three plants were planted in each bucket.

The treatments consisted of control (no-NaCl) and $1760 \mathrm{mg} \mathrm{L}^{-1}, 2400 \mathrm{mg} \mathrm{L}^{-1}, 3040 \mathrm{mg} \mathrm{L}^{-1}$ of NaCl (which are equal to $2.75 \mathrm{dS} \mathrm{m}^{-1}, 3.75 \mathrm{dS} \mathrm{m}^{-1}$ and $4.75 \mathrm{dS} \mathrm{m}^{-1}$ salinity respectively) in half-strength Hoagland nutrient solution. Tap water used in the preparation of the treatments contains approximately $109.57 \mathrm{mg} \mathrm{L}^{-1} \mathrm{Na}$ and $7.1 \mathrm{mg} \mathrm{L}^{-1} \mathrm{Cl}$. Salinity treatments were started 30 days after planting. The pots irrigated with an amount of $\mathrm{NaCl}$-enriched half concentrated Hoagland solution accounting for a leaching factor of 20-25\% (Hoagland and Arnon, 1950) for six months. Each treatment was replicated 3 times with 2 buckets, 3 plants per bucket, hence 6 buckets and 18 plants per replicate.

\section{Sampling and chemical analyses}

Leaf and root sampling were performed two times with five months interval in full bloom periods of the plants. For this purpose the first three buckets in the each replication were emptied on January 2, 2005 and the second three buckets were emptied on May 1, 2005. The plants were gently removed from the sand and partitioned into roots and leaves. The roots were selected by hand mechanically from the sand. For plant analysis, physiologically mature leaves of the same physiological age, free of damage or defects, were sampled. The samples were immediately transported to the laboratory in closed polyethylene bags and carefully washed with tap water, rinsed in deionized water, and dried in a forced-air oven at $70^{\circ} \mathrm{C}$ for $72 \mathrm{~h}$ in paper bags. Dried samples were ground in a stainless steel coffee grinder. The ground samples were wet digested in a mixture of nitric acid/perchloric acid $\left(\mathrm{HNO}_{3} / \mathrm{HClO}_{4}\right)(4 / 1, \mathrm{v} / \mathrm{v})$ solution (Westerman, 1990). Sodium contents in the digest were determined using flame photometry (Jenway PFP7, Staffordshire, UK), P by the vanadomolybdophosphoric method (Westerman, 1990). The total $\mathrm{N}$ content of the dried samples were analyzed by Kjeldahl digestion method (Westerman, 1990). For the $\mathrm{N}$ analysis, $0.25 \mathrm{~g}$ of the samples was wet digested in a heating digester (Velp Scientifica, DK20, Milano, Italy) and then distilled in a distillation unit (Velp Scientifica, UDK126A, Milano, Italy). Aliquots were titrated by $0.1 \mathrm{~N} \mathrm{HCl}$. The results were expressed as the $\% \mathrm{~N}$ in the dry matter. The $\mathrm{Cl}$ was extracted from $0.1 \mathrm{~g}$ of the ground sample with 10 $\mathrm{ml}$ of deionized water by shaking the mixture for $2 \mathrm{~h}$. The $\mathrm{Cl}$ concentrations of the extracts were measured by a chloridmeter (Jenway PCLM3, Staffordshire, UK). The results were expressed as the $\% \mathrm{Cl}$ in the dry matter (Brown and Jackson, 1955).

Analysis of variance (ANOVA) procedures were performed in Three Factors Completely Randomized Design for plant analysis results according to Little and Hills (1978). Additionally orthogonal comparison was applied to the significant salinity effects.

\section{Results}

Variance analyses results of the effects on the cultivars, sampling time and salinity on $\mathrm{N}, \mathrm{P}, \mathrm{Na}$ and $\mathrm{Cl}$ concentrations of the roots and the leaves were given in Table 1. Cultivar and sampling time affected N, P, Na and $\mathrm{Cl}$ concentrations of the roots significantly. Cultivar-sampling time and sampling time-salinity 
interactions were significant for the $\mathrm{N}, \mathrm{P}$ and $\mathrm{Na}$ concentrations of the roots. Salinity solely affected $\mathrm{Cl}$ concentrations of the roots significantly. All the treatments affected $\mathrm{Cl}$ concentration of the roots however the interactions between the treatments were nonsignificant.

Table 1. Variance analysis results of the effects of cultivar, sampling time and salinity on N, P, $\mathrm{Na}$ and $\mathrm{Cl}$ concentrations of the roots and the leaves

\begin{tabular}{|c|c|c|c|c|c|c|c|c|}
\hline \multirow[t]{2}{*}{ Treatments and interactions } & \multicolumn{4}{|c|}{ Nutrients in the roots } & \multicolumn{4}{|c|}{ Nutrients in the leaves } \\
\hline & $\mathrm{N}$ & $\mathrm{P}$ & $\mathrm{Na}$ & $\mathrm{Cl}$ & $\mathrm{N}$ & $\mathrm{P}$ & $\mathrm{Na}$ & $\mathrm{Cl}$ \\
\hline A-Cultivar & $* *$ & ** & $* *$ & ** & ns & $* *$ & $*$ & ** \\
\hline B-Sampling Time & $* *$ & $* *$ & $* *$ & $* *$ & $* *$ & $* *$ & $* *$ & $* *$ \\
\hline C-Salinity & ns & ns & ns & $* *$ & ns & $* *$ & $* *$ & $* *$ \\
\hline AxB Interaction & $*$ & $* *$ & $* *$ & ns & ns & $* *$ & ns & ns \\
\hline AxC Interaction & ns & ns & ns & ns & $* *$ & ns & ns & ns \\
\hline BxC Interaction & $*$ & $*$ & $* *$ & ns & $*$ & $* *$ & ns & ns \\
\hline AxBxC Interaction & ns & ns & ns & ns & ns & ns & ns & ns \\
\hline
\end{tabular}

${ }^{*} \mathrm{P} \leq 0.05,{ }^{* *} \mathrm{P} \leq 0.01$, ns: nonsignificant

All the treatments affected the concentrations of $\mathrm{P}, \mathrm{Na}$ and $\mathrm{Cl}$ of the leaves significantly. In other words, different levels of $\mathrm{P}, \mathrm{Na}$ and $\mathrm{Cl}$ concentrations of the cultivars altered according to sampling time and salinity levels. The $\mathrm{N}$ concentrations of the leaves were affected by only sampling time. Cultivar-salinity and sampling time-salinity interactions were found significant in the leaf $\mathrm{N}$ concentrations of the plants.

Cultivar-sampling time and sampling time-salinity interactions were significant for the leaf $\mathrm{P}$ concentrations of the plants. None of the interactions between the treatments were significant for $\mathrm{Na}$ and $\mathrm{Cl}$ concentrations of the leaves. Interaction between the cultivar and sampling time for $\mathrm{N}, \mathrm{P}$ and $\mathrm{Na}$ concentrations of the roots were seen in Table 2. Nitrogen and $\mathrm{P}$ concentrations of the cultivars decreased, and $\mathrm{Na}$ concentration increased with time.

Table 2. Interaction between cultivar and sampling time in respect to root $\mathrm{N}, \mathrm{P}$ and $\mathrm{Na}$ concentrations

\begin{tabular}{lcccccc}
\hline \multirow{2}{*}{ Cultivar } & \multicolumn{2}{c}{ Root N $(\%)$} & \multicolumn{2}{c}{ Root P (\%) } & \multicolumn{2}{c}{ Root Na (\%) } \\
\cline { 2 - 7 } & January & May & January & May & January & May \\
\hline Camarosa & $3.25^{*}$ & 1.71 & 0.33 & 0.06 & 0.31 & 0.39 \\
Sweet Charlie & 3.87 & 2.08 & 0.35 & 0.13 & 0.56 & 0.76 \\
\hline
\end{tabular}

Interaction and orthogonal comparisons between the sampling times and the salinity levels for the root $\mathrm{N}, \mathrm{P}$ and $\mathrm{Na}$ concentrations were given in Table 3 and Table 4 respectively. Root $\mathrm{N}$ and $\mathrm{P}$ concentrations of the cultivars decreased and root $\mathrm{Na}$ concentrations increased with time (Table 3). Compared to the control treatment, increasing salinity levels enhanced the $\mathrm{N}$ and $\mathrm{P}$ concentrations of the roots in the first sampling time. This effect was linear for the $\mathrm{N}$ concentration. However aforesaid relations were nonsignificant in the second sampling time. Salinity treatments increased the concentration of $\mathrm{Na}$ of the roots linearly. Nitrogen and $\mathrm{P}$ concentrations of the roots were affected in the first sampling time (Table 4).

Table 3. Interaction between sampling time and salinity in respect to root $\mathrm{N}, \mathrm{P}$ and Na concentrations

\begin{tabular}{|c|c|c|c|c|c|}
\hline \multirow{2}{*}{ Plant Nutrients (\%) } & \multirow{2}{*}{ Sampling Time } & \multicolumn{4}{|c|}{ Salinity $\left(\mathrm{dS} \mathrm{m}^{-1}\right)$} \\
\hline & & Control & 2.75 & 3.75 & 4.75 \\
\hline \multirow{2}{*}{$\mathrm{N}$} & January & $3.41^{*}$ & 3.41 & 3.68 & 3.74 \\
\hline & May & 1.93 & 1.87 & 1.91 & 1.87 \\
\hline \multirow{2}{*}{$\mathrm{P}$} & January & 0.31 & 0.34 & 0.34 & 0.37 \\
\hline & May & 0.10 & 0.10 & 0.09 & 0.09 \\
\hline \multirow{2}{*}{$\mathrm{Na}$} & January & 0.15 & 0.31 & 0.54 & 0.76 \\
\hline & May & 0.45 & 0.52 & 0.50 & 0.84 \\
\hline
\end{tabular}

Table 4. Orthogonal comparison of sampling time-salinity interaction in respect to root N, P and Na concentrations

\begin{tabular}{lllll}
\hline Sampling Time & Comparison & $\mathrm{N}$ & $\mathrm{P}$ & \\
\multirow{4}{*}{ January } & Control vs. other Treatments & $*$ & $* *$ & $\mathrm{Na}$ \\
& Salinity-Linear & $* *$ & $\mathrm{~ns}$ & $* *$ \\
& Salinity-Quadratic & $\mathrm{ns}$ & $\mathrm{ns}$ & $\mathrm{ns}$ \\
\hline \multirow{3}{*}{ May } & Control vs. other Treatments & $\mathrm{ns}$ & $\mathrm{ns}$ & ns \\
& Salinity-Linear & $\mathrm{ns}$ & $\mathrm{ns}$ & $* *$ \\
\hline
\end{tabular}

$* \mathrm{P} \leq 0.05, * * \mathrm{P} \leq 0.01, \mathrm{~ns}$ : nonsignificant 
Interaction between the cultivar and the salinity for the leaf $\mathrm{N}$ concentration, and their orthogonal comparisons were given in Table 5 and Table 6 respectively. The salinity affected leaf $\mathrm{N}$ concentrations of the cultivars in different ways. The leaf $\mathrm{N}$ concentration of Camarosa was stable, but the leaf $\mathrm{N}$ concentration of Sweet Charlie increased (Table 5). Probably the difference between the cultivars made the main effects of the salinity on leaf $\mathrm{N}$ concentration nonsignificant (Table 1). Compared to the control treatment, salinity levels increased the leaf $\mathrm{N}$ concentrations of Sweet Charlie, additionally salinity treatments affected the leaf $\mathrm{N}$ concentrations of this cultivar quadraticly. In other words, the second salinity level $\left(3.75 \mathrm{dS} \mathrm{m}^{-1}\right)$ increased the leaf $\mathrm{N}$ concentration compared to the first salinity level $\left(2.75 \mathrm{dS} \mathrm{m}^{-1}\right)$, however the third salinity level $\left(4.75 \mathrm{dS} \mathrm{m}^{-1}\right)$ decreased the leaf $\mathrm{N}$ concentration of Sweet Charlie compared to the second salinity level (3.75 $\mathrm{dS} \mathrm{m}^{-1}$ ) (Table 6).

Table 5. Interaction between cultivar and salinity in respect to leaf $\mathrm{N}$ concentrations (\%)

\begin{tabular}{lcccc}
\hline \multirow{2}{*}{ Cultivar } & \multicolumn{4}{c}{ Salinity $\left(\mathrm{dS} \mathrm{m}^{-1}\right)$} \\
\cline { 2 - 5 } & Control & 2.75 & 3.75 & 4.75 \\
\hline Camarosa & $2.24^{*}$ & 2.26 & 2.18 & 2.27 \\
Sweet Charlie & 2.18 & 2.16 & 2.37 & 2.34 \\
\hline
\end{tabular}

Table 6. Orthogonal comparison of cultivar-salinity interaction in respect to leaf $\mathrm{N}$ concentrations

\begin{tabular}{|c|c|c|}
\hline Cultivar & Comparison & \\
\hline \multirow{3}{*}{ Camarosa } & Control vs. other Treatments & ns \\
\hline & Salinity-Linear & ns \\
\hline & Salinity-Quadratic & ns \\
\hline \multirow{3}{*}{ Sweet Charlie } & Control vs. other Treatments & $*$ \\
\hline & Salinity-Linear & $* *$ \\
\hline & Salinity-Quadratic & $*$ \\
\hline
\end{tabular}

${ }^{*} \mathrm{P} \leq 0.05,{ }^{* *} \mathrm{P} \leq 0.01, \mathrm{~ns}$ : nonsignificant

Interaction between the sampling time and the salinity for the leaf $\mathrm{N}$ and $\mathrm{P}$ concentrations, and their orthogonal comparisons were given in Table 7 and Table 8 respectively. In general, the leaf $\mathrm{N}$ concentration of the cultivars increased with time, the leaf P concentration of the cultivars decreased with time (Table 7). The effects of the salinity levels on the leaf $\mathrm{N}$ and $\mathrm{P}$ concentrations of the cultivars disappeared in the second sampling times (Table 8). Salinity treatments increased the leaf $\mathrm{N}$ and $\mathrm{P}$ concentrations linearly in the first sampling time (Table 8).

Table 7. Interaction between sampling time and salinity in respect to leaf N (\%) and P concentrations (\%)

\begin{tabular}{lccccc}
\hline \multirow{2}{*}{ Plant Nutrients (\%) } & \multirow{2}{*}{ Sampling Time } & \multicolumn{4}{c}{ Salinity $\left(\mathrm{dS} \mathrm{m}\right.$ - $\left.^{-1}\right)$} \\
\cline { 3 - 6 } & & Control & 2.75 & 3.75 & 4.75 \\
\multirow{2}{*}{$\mathrm{N}$} & January & $2.13^{*}$ & 2.10 & 2.19 & 2.31 \\
& May & 2.30 & 2.33 & 2.37 & 2.30 \\
\hline \multirow{2}{*}{$\mathrm{P}$} & January & 0.40 & 0.41 & 0.44 & 0.48 \\
& May & 0.20 & 0.22 & 0.20 & 0.21 \\
\hline
\end{tabular}

Table 8. Orthogonal comparison of sampling time-salinity interaction in respect to leaf N (\%) and P concentrations (\%)

\begin{tabular}{llll}
\hline Sampling Time & Comparison & $\mathrm{N}$ & $\mathrm{P}$ \\
\hline \multirow{3}{*}{ January } & Control vs. other Treatments & $\mathrm{ns}$ & $* *$ \\
& Salinity-Linear & $* *$ & $* *$ \\
& Salinity-Quadratic & $\mathrm{ns}$ & $\mathrm{ns}$ \\
\hline \multirow{2}{*}{ May } & Control vs. other Treatments & $\mathrm{ns}$ & $\mathrm{ns}$ \\
& Salinity-Linear & $\mathrm{ns}$ & $\mathrm{ns}$ \\
& Salinity-Quadratic & $\mathrm{ns}$ & $\mathrm{ns}$ \\
\hline
\end{tabular}

** $\mathrm{P} \leq 0.01, \mathrm{~ns}$ : nonsignificant

Interaction between the cultivar and sampling time for the leaf $\mathrm{P}$ concentration were given in Table 9. The leaf $\mathrm{P}$ concentrations of the cultivars decreased with time.

Table 9. Interaction between cultivar and sampling time in respect to leaf $\mathrm{P}$ concentrations (\%)

\begin{tabular}{lcc}
\hline \multirow{2}{*}{ Cultivar } & \multicolumn{2}{c}{ Sampling Time } \\
\cline { 2 - 4 } & January & May \\
\hline Camarosa & $0.39^{*}$ & 0.20 \\
Sweet Charlie & 0.47 & 0.21 \\
\hline
\end{tabular}


The effects of salinity on leaf $\mathrm{Na}$, leaf $\mathrm{Cl}$ and root $\mathrm{Cl}$ concentrations, and their orthogonal comparisons were given in Table 10 and Table 11 respectively. The salinity treatments increased the concentrations of the related plant nutrients linearly.

Table 10. Effect of salinity on root $\mathrm{Cl}$ and leaf $\mathrm{Na}$ and $\mathrm{Cl}$ concentrations

\begin{tabular}{lcccc}
\hline \multirow{2}{*}{ Plant Nutrients (\%) } & \multicolumn{4}{c}{ Salinity $\left(\mathrm{dS} \mathrm{m}^{-1}\right)$} \\
\cline { 2 - 5 } & Control & 2.75 & 3.75 & 4.75 \\
\hline Leaf Na & $0.01^{*}$ & 0.02 & 0.04 & 0.06 \\
Leaf Cl & 0.42 & 0.54 & 0.73 & 0.84 \\
Root Cl & 0.24 & 0.32 & 0.38 & 0.53 \\
\hline
\end{tabular}

Table 11. Orthogonal comparison of salinity effect on root $\mathrm{Cl}$, leaf $\mathrm{Na}$ and $\mathrm{Cl}$ concentrations

\begin{tabular}{|c|c|c|c|}
\hline \multirow[b]{2}{*}{ Interaction } & \multicolumn{2}{|c|}{ Comparison of the nutrients in the leaves } & \multirow{2}{*}{$\begin{array}{l}\text { Comparison of the nutrients in the roots } \\
\mathrm{Cl}\end{array}$} \\
\hline & $\mathrm{Na}$ & $\mathrm{Cl}$ & \\
\hline Control vs. other Treatments & ** & ** & ** \\
\hline Salinity-Linear & ** & ** & ** \\
\hline Salinity-Quadratic & ns & ns & ns \\
\hline
\end{tabular}

** $\mathrm{P} \leq 0.01$, ns: nonsignificant

\section{Discussion}

The results of the mineral analyses showed that the cultivars probably have different strategies in point of the organization of $\mathrm{Na}$ in plants. Compared to the Camarosa, the root Na concentrations of the Sweet Charlie were approx. 45\% and 49\% higher for the sampling times of the January and the May respectively (Table 2). But it has slightly lower leaf Na concentration than that of Camarosa (The data not shown). Probably Camarosa tended to limit the entry of $\mathrm{Na}$ into the roots while Sweet Charlie tended to prevent translocation of $\mathrm{Na}$ to the leaves. In other words, Sweet Charlie has low translocation potential or a feedback control, from demand by vegetative growth that regulates the uptake and translocation from root to aerial parts. According to Jacoby (1979), ions accumulate in the root or in the basal part of the shoot, from where return to the root system and excreted into the medium. The efficiency of these exclusion processes varies among soybean (Durand and Lacan 1994) and olive (Demiral, 2005) cultivars, and can be considered as one of the mechanisms for maintenance of low leaf-Na concentration in plants.

Salt-tolerant plants differ from salt-sensitive ones in having a low rate of $\mathrm{Na}$ and $\mathrm{Cl}$ transport to leaves (Munns, 2002). Ulrich et al. (1980) report $\mathrm{Na}$ toxicities with concentrations greater than $0.1 \% \mathrm{Na}$ in strawberry. Although there were differences in the root and leaf concentrations of Na between the cultivars, the leaf Na content of the cultivars did not exceed $0.05 \%$ in the study. Hence, the cultivars showed similar response in this point.

Chloride should also be appreciated in determination of salinity resistance level of plants. This element is absorbed by cell membranes and translocated easily to the upper plant parts compared to Na. Therefore, its level is generally higher than that of $\mathrm{Na}$ in upper plant parts although it is a trace element (Marschner, 1995). In this study, the cultivars significantly differed in the concentrations of $\mathrm{Cl}$ in their tissues (Table 1). Compared to the Sweet Charlie, $\mathrm{Cl}$ concentrations of root and leaf of Camarosa were lower both in the January and in the May sampling (Figures 1,2). Hence Camarosa can be rated as more tolerant cultivar to $\mathrm{Cl}$ in soil solution or in irrigation water. According to Grieve et al. (2003), the salt tolerance of soybean is positively correlated with $\mathrm{Cl}$ exclusion from the leaves and salt-sensitive cultivars' leaves are severely injured due to $\mathrm{Cl}$ toxicity and contained 10-15 times more $\mathrm{Cl}$ than the tolerant $\mathrm{Cl}$ excluding varieties. As reported by Demiral et al. (2005), salt-sensitive barley cultivar Kaya accumulated more $\mathrm{Cl}$ in leaves than salttolerant barley cultivar Scarlet.

Strawberry plant is sensitive to high $\mathrm{Cl}$ contents in root area (Lieten, 1997). Leaf Cl contents higher than $0.5 \%$ causes necrosis in leaves and yield reduce for most of the strawberry cultivars (Ulrich et al., 1980). In the study, increase in duration of salinity led the cultivars to exceed this limit in the second sampling period. Lieten (1997) stated that leaf $\mathrm{Cl}$ content of $\mathrm{cv}$. Elsanta does not exceed $0.5 \%$ and shows no any toxicity symptoms in leaves under salinity.

Compared to the Camarosa, the root $\mathrm{N}$ concentrations of Sweet Charlie were approx. $18 \%$ and $16 \%$ higher for the sampling times of the January and the May respectively (Table 2). This phenomenon probably deals with the higher tissue $\mathrm{Cl}$ concentrations of Sweet Charlie than that of Camarosa (Figures 1, 2). Inhibition of 
$\mathrm{NO}_{3}{ }^{-}$translocation to the leaves by $\mathrm{Cl}^{-}$would result in an accumulation of $\mathrm{NO}_{3}{ }^{-}$in the roots (Rubinigg et al., 2003). According to the authors there might be a negative effect of $\mathrm{NaCl}$ on the translocation of $\mathrm{NO}_{3}$ - from root to the aerial parts of the plants. As reported by Köhler and Raschke (2000) the anion channels with similar permeability for both $\mathrm{NO}_{3}{ }^{-}$and $\mathrm{Cl}^{-}$in xylem parencyhma cells play a significant role in the xylem loading of $\mathrm{NO}_{3}{ }^{-}$and $\mathrm{Cl}$. In the presence of high $\mathrm{Cl}^{-}$concentrations, root to aerial parts translocation of $\mathrm{NO}_{3}{ }^{-}$ could therefore be decreased at the site of entrance into the xylem via competition for the same channel.

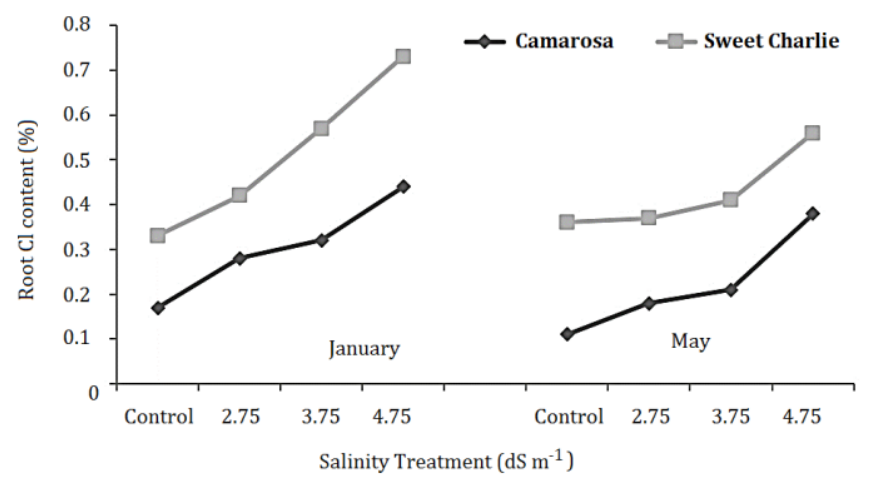

Figure 1. Variation in root $\mathrm{Cl}$ content of the cultivars under salinity in different sampling times

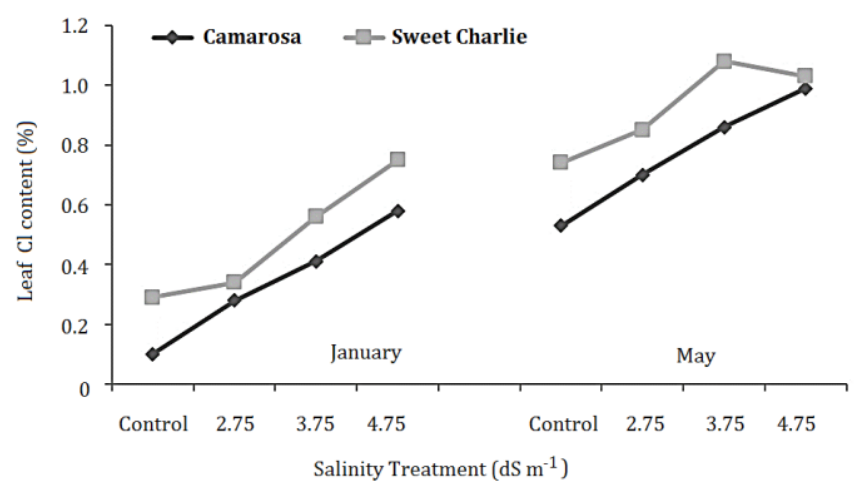

Figure 2. Variation in leaf $\mathrm{Cl}$ content of the cultivars under salinity in different sampling times

Another probable reason of high $\mathrm{N}$ concentration in plant tissues is increased synthesis of amino- $\mathrm{N}$ compounds as a plant response to salt stress. Probably increasing sensitivity of the plants to the salinity increased the synthesis of this kind of biochemical compounds in plants (Storey and Wyn-Jones, 1977). According to Loupassaki et al. (2002) salt sensitive olive cultivars have higher $\mathrm{N}$ concentration in their tissues. In the light of the data given above it can be concluded that Sweet Charlie is more salt sensitive cultivar than that of Camarosa and more salt sensitive plants have higher $\mathrm{N}$ concentrations in their roots than salt tolerant ones.

Salinity increased the $\mathrm{N}$ concentrations of the roots (Table 3). However this tendency disappeared in the second sampling time (Tables 3,4 ). Compared to the sampling time of the January, the root $\mathrm{N}$ concentrations of the cultivars were approx. $47 \%$ lower in the sampling time of the May (Table 2). This might be a result of decreased $\mathrm{NO}_{3}$ - influx under increasing $\mathrm{Cl}^{-}$concentrations in plant tissues with time. According to Botella et al. (1994) Cl- exerted a negative effect on $\mathrm{NO}_{3}$ - uptake in Triticum aestivum, but could not specify whether the observed interaction was due to competitive inhibition or not.

The cultivars have lower concentrations of $\mathrm{N}$ in their leaves than that of their roots (Tables 2,5 ). The lower $\mathrm{N}$ concentrations of the leaves of the plants could be the consequence of a generally lower rate of solute flow in the xylem as a result of a reduced transpiration rate for $\mathrm{NO}_{3}$ or amino acids, a lower requirement for $\mathrm{NO}_{3}-$ in the aerial parts of the plants, or a decreased $\mathrm{NO}_{3}$ - influx (Rubinigg et al., 2003). The concentrations of $\mathrm{N}$ of Sweet Charlie leaves significantly increased with the salinity (Table 5, 6). However this interaction was nonsignificant for Camarosa (Table 6). This result might be related to the different response of the cultivars to the salinity.

Compared to the sampling time of January, the $\mathrm{N}$ concentrations of the cultivars' leaves increased in the sampling time of May (Table 7). This might be related to the high amounts of the organic solutes synthesized under increased salinity stress resulted from increasing salinity level and salinity duration or a concentration effect due to growth depression. This tendency was significant in the January but in the May (Table 8).

The cultivars have more or less similar concentrations of $\mathrm{P}$ in their roots in the sampling time of January. However root $P$ concentrations of the cultivars decreased significantly in the sampling time of May (Table 2). A similar tendency was also seen in the leaf P concentrations of the cultivars (Table 9).

Controversy, concerns about the effect of salinity on P concentrations of plants is reflected in the literature. Some researchers reported that salinity decreased P concentrations of plant tissues. According to Cangi and Tarakçığlu (2006) compared to control, $40 \mathrm{mM} \mathrm{NaCl}$ application decreased $\mathrm{P}$ in roots but increased in both leaves and shoots of kivifruit. Shibli et al. (2001) reported decreased of P in the shoots of Saintpalia 
ionantha. Our results disagree with the aforementioned reports. On the other hand the results of some other studies indicated that salinity may increase P concentrations of the plants (Navarro et al., 2001; Loupassaki et al., 2002). Keutgen and Pawelzik (2009) found increased concentrations of P in roots and petioles of salt stressed strawberry cultivars Korona and Elsanta. Our results confirmed this increase of root (Tables 3 ) and leaf $\mathrm{P}$ concentrations in both cultivars in the sampling time of January but in the sampling time of May (Table 7). Sweet Charlie has both higher concentration of $\mathrm{Cl}$ (Figure 1,2) and higher concentration of $\mathrm{P}$ in its tissues than that of Camarosa (Tables 2 and 9). Salinity imposed by $\mathrm{Cl}$ salts stimulated $\mathrm{P}$ uptake in plants (Cerda et al., 1977; Kasırğa and Demiral, 2016) and such increase of P levels is not a result of concentration effect due to growth depression (Roberts et al., 1984). According to Furihata et al. (1992) plants have two different $P$ uptake systems: one with a high affinity (uptake of $\mathrm{P}$ at low $\mathrm{P}$ concentrations) and one with a lower affinity (uptake of $\mathrm{P}$ at higher $\mathrm{P}$ concentrations). The low affinity system is considered constitutive (Dunlop et al., 1997) and its activity is connected with the existence of multiple transporters of $P$ in the plasma membrane and tonoplast (Schachtman et al., 1998). The transporters are regulated by the external $\mathrm{P}$ concentration (Leggewie et al., 1997) and high cytosol pH (Martinez and Lauchli, 1994). Most likely salinity increased the $P$ uptake of the experimental plants through low affinity system and the salt-induced alkalinization of cytosols contributed to the process.

In conclusion; the results of the study showed that the cultivars and sampling times affected $\mathrm{N}, \mathrm{P}, \mathrm{Na}$ and $\mathrm{Cl}$ concentrations of the plants significantly. Under increasing salinity Camarosa suppressed better the concentrations of $\mathrm{Na}$ and $\mathrm{Cl}$ of the plant tissues than that of Sweet Charlie. Therefore Camarosa is rated as more tolerant cultivar to $\mathrm{Na}^{+}$and $\mathrm{Cl}^{-}$ions in soil solution or in irrigation water. The effects of increasing salinity on plant nutrients tested have lost its significance over time. This is probably related to the increasing damage constituted by the extended stress to the plant metabolism. The cultivars showed different responses in terms of $\mathrm{N}$ and $\mathrm{P}$ contents under increasing salinity. Sweet Charlie had higher $\mathrm{N}$ concentrations in their tissues than that of the Camarosa. This reaction is evaluated as a sign of higher sensibility to salt stress. Salinity increased the P concentrations of the experimental plants and the cultivars had more or less similar concentrations of $\mathrm{P}$ in their tissues under salinity. This tendency is attributed to the changes in P uptake system of the plants that arising from the salinity.

\section{Acknowledgements}

I thank to Professor Dr. A. Turgut Köseoğlu for helpful suggestions on the manuscript. I also thank Mr. Bayram Altunç for his technical assistance.

\section{References}

Awang, Y.B., Atherton, J.G., Taylor, A.J., 1993a. Salinity effects on strawberry plants grown in rockwool. I. Growth and leaf water relations. Journal of Horticultural Science 68(5): 783-790.

Awang, Y.B., Atherton, J.G., Taylor, A.J., 1993b. Salinity effects on strawberry plants grown in rockwool. I. Fruit quality. Journal of Horticultural Science 68(5): 791-795.

Botella, M.A., Cerdá, A., Lips, S.H., 1994. Kinetics of $\mathrm{NO}_{3}^{-}$and $\mathrm{NH}_{4}{ }^{+}$uptake by wheat seedlings. Effect of salinity and nitrogen source. Journal of Plant Physiology 144(1): 53-57.

Botella, M.A., Martínez, V., Nieves, M., Cerdá, A., 1997. Effect of salinity on the growth and nitrogen uptake by wheat seedlings. Journal of Plant Nutrition 20(6): 793-804.

Brown, J.G., Jackson, R.K., 1955. A note on the potentiometric determination of chloride. Proceedings of the American Society for Horticultural Science 65: 187-193.

Cangi, R., Tarakcioglu, C., 2006. Effects of sodium chloride ions on growth and mineral contents of kiwifruit plants. Asian Journal of Chemistry 18(3): 1871-1878

Carter, D.L., 1981. Salinity and plant productivity. In: Handbook series in nutrition and food. Chemical Rubber Co., Cleveland, OH, USA. pp.146-151.

Cerda, A., Bingham, F.T., Hoffman, G., 1977. Interactive effect of salinity and phosphorus on sesame. Soil Science Society of America Journal 41(5): 915-918.

Demiral, M.A., 2005. Comparative response of two olive (Olea europaea L.) cultivars to salinity. Turkish Journal of Agriculture and Forestry 29(4): 267-274.

Demiral, M.A., Aydin, M., Yorulmaz, A., 2005. Effect of salinity on growth chemical composition and antioxidative enzyme activity of two malting barley (Hordeum vulgare L.) cultivars. Turkish Journal of Biology 29(2): 117-123.

Dunlop, J., Phung, H.T., Meeking, R., White, D.W.R., 1997. The kinetics associated with phosphate absorption by Arabidopsis and its regulation by phosphorus status. Australian Journal of Plant Physiology 24(5): 623-629.

Durand, M., Lacan, D., 1994. Sodium partitioning within the shoot of soybean. Physiologia Plantarum 91(1): 65-71. 
Furihata, T., Suzuki, M., Sakurai, H., 1992. Kinetic characterization of two phosphate uptake systems with different affinities in suspension-cultured Catharanthus roseus protoplasts. Plant and Cell Physiology 33(8): 1151-1157.

Ghafoor, A., Qadir, M., Murtaza, G., 2004. Salt-affected soils: Principles of management. Allied Book Centre Publications, Lahore, Pakistan. pp. 110-123.

Gorham, J., 1992. Salt tolerance of plants. Science Progress 76(3-4): 273-285.

Grieve, C.M., Wang, D., Shannon, M.C., 2003. Salinity and irrigation method affect mineral ion relations of soybean. Journal of Plant Nutrition 26(4): 901-913.

Hoagland, D.R., Arnon, D.I.,1950. The water-culture method for growing plants without soil. University of California, College of Agriculture, California Agricultural Experiment Station, Circular No. 347. Berkeley, USA. 39p.

Jacoby, B., 1979. Sodium recirculation and loss from Phaseolus vulgaris L. Annals of Botany 43(6): 741-744.

Kalifa, A., Barthakur, N.N., Donnelly, D.J., 2000. Phosphorus reduces salinity stress in micropropated potato. American Journal of Potato Research 77(3): 179-182.

Kasırğa, E., Demiral, M.A., 2016. Salt stress-mineral nutrient relations in olive (Olea europaea L.) plant . Eurasian Journal of Soil Science 5 (4): 307- 313.

Keutgen, A.J., Pawelzik, E., 2009. Impacts of $\mathrm{NaCl}$ stress on plant growth and mineral nutrient assimilation in two cultivars of strawberry. Environmental and Experimental Botany 65(2-3): 170-176.

Köhler, B., Raschke, K., 2000. The delivery of salts to the xylem. Three types of anion conductance in the plasmalemma of the xylem parenchyma of roots of barey. Plant Physiology 122(1): 243-254.

Larson, K.D., 1994. Strawberry, In: Handbook of environmental physiology of fruit crops. Vol. 1. Temperate crops. Schaffer, B., Anderson, P.C. (Eds.). CRC Press, Boca Raton, USA. pp. 271-297.

Leggewie, G., Wilmitzer, L., Riesmeier, J.W., 1997. Two cDNAs from potato are able to complement a phosphate uptakedeficient yeast mutant: identification of phosphate transporters from higher plants. The Plant Cell 9(3): 381-632.

Lieten, F., 1997. Chloride nutrition of strawberries grown on peat bags. Journal of Small Fruit \& Viticulture 5(1): 51-61.

Little, T.M., Hills, F.J., 1978. Agricultural experimentation: design and analysis. John Wiley and Sons Inc. New York, USA, $350 \mathrm{p}$.

Loupassaki, M.H., Chartzoulakis, K.S., Digalaki, N.B., Androulakis I.I., 2002. Effects of salt stress on concentration of nitrogen, phosphorus, potassium, calcium, magnesium and sodium in leaves, shoots and roots of six olive cultivars. Journal of Plant Nutrition 25(11): 2457-2482.

Martinez, V., Läuchli, A., 1994. Salt-induced inhibition of phosphate uptake in plants of cotton (Gossypium hirsutum L.). New Phytologist 126(4): 609-614.

Marschner, H., 1995. Mineral nutrition of higher plants. 2nd Edition. Academic Press, London. UK. 901p.

Munns, R., 2002. Comparative physiology of salt and water stress. Plant, Cell and Environment 25(2): 239-250.

Navarro, J.M., Botella, M.A., Cerdá, A., Martinez, V., 2001. Phosphorus uptake and translocation in salt-stressed melon plants. Journal of Plant Physiology 158(3): 375-381.

Orcutt, D.M., Nielsen, E.T., 2000. The physiology of plants under stress: Soil and Biotic Factors. John Wiley and Sons Inc. New York, USA. 696p.

Roberts, J.K.M., Linker, C.S., Benoit, A.G., Jardetzky, O., Nieman, R.H., 1984. Salt stimulation of phosphate uptake in maize root tips studied by ${ }^{31} \mathrm{P}$ nuclear magnetic resonance. Plant Physiology 75(4): 947-950.

Rubinigg, M., Posthumus, F., Ferschke, M., Elzenga, J.T.M., Stulen, I., 2003. Effects of NaCl salinity on ${ }^{15} \mathrm{~N}-$ nitrate fluxes and specific root length in the halophyte Plantago maritima L. Plant and Soil 250(2): 201-213.

Schachtman, P., Reid, R.J., Ayling, S.M., 1998. Phosphorus uptake by plants: from soil to cell. Plant Physiology 116(2): 447-453.

Shibli, R.A., Sawwan, J., Swaidat, I., Tahat, M., 2001. Increased phosphorus mitigates the adverse effects of salinity in tissue culture. Communication in Soil Science and Plant Analysis 32(3-4): 429-440.

Storey, R., Wyn-Jones, R.G., 1977. Quarternary ammonium compounds in plants in relation to salt resistance. Phytochemistry 16(4): 447-453.

Ulrich, A., Mostafa, M.A.E., Allen, W.W., 1980. Strawberry deficiency symptoms: A visual and plant analysis guide to fertilization. University of California, Division of Agricultural Sciences, Publication No. 4098, California, USA. 58p.

Westerman, R.L., 1990. Soil testing and plant analysis. Soil Science Society of America (SSAA) Book Series, Vol. 3, Issue 3. SSSA Publications, Madison, Wisconsin, USA. 784p. 